\title{
Evaluasi Desain Terminal Penumpang Bandara New Yogyakarta International Airport
}

\author{
Deanty Putri Maritsa dan Ervina Ahyudanari \\ Departemen Teknik Sipil, Fakultas Teknik Sipil dan Perencanaan, Institut Teknologi Sepuluh Nopember (ITS) \\ e-mail: ervina@ce.its.ac.id
}

\begin{abstract}
Abstrak-Terminal penumpang bandara New Yogyakarta International Airport (NYIA) didesain dengan dua desain yang berbeda, desain pier yang disajikan oleh AGA-Letiste (perusahaan asing yang berasal dari Republik Ceko) melalui website-nya dan desain linear yang direalisasikan oleh PT Angkasa Pura 1 (Persero). Perbedaan desain tersebut menimbulkan pertanyaan mengenai efisiensi konsep desain terminal linear yang digunakan dalam memenuhi pertumbuhan jumlah penumpangnya. Sehingga, untuk menjawab pertanyaan ini, dibutuhkan suatu evaluasi terhadap konsep desain terminal penumpang bandara NYIA guna mencegah permasalahan ketidaknyamanan penumpang terhadap pelayanan penumpang di Bandara Adisucipto Yogyakarta. Dalam penyelesaian studi ini, dilakukan peramalan jumlah penumpang dengan menggunakan metode peramalan ARIMA dan Triple Exponential Smoothing. Peramalan jumlah penumpang dilakukan untuk mengetahui pertumbuhan pergerakan penumpang di Bandara NYIA pada tahun 2017-2040. Setelah itu dilakukan evaluasi desain terminal penumpang untuk mengetahui efisiensi dari desain terminal linear yang digunakan di Bandara NYIA. Terakhir dilakukan analisis nilai Level of Service (LOS) pada terminal penumpang bandara NYIA untuk mengetahui pada tahun berapa desain terminal linear perlu dikembangkan. Dari hasil analisis data jumlah penumpang Bandara Adisucipto Yogyakarta, dapat diketahui bahwa pertumbuhan pergerakan penumpang di Bandara Adisucipto Yogyakarta pada tahun 2017-2040 mengalami peningkatan rata-rata sebesar $7.90 \%$ setiap tahunnya. Dari hasil analisis desain terminal penumpang, dapat diketahui bahwa desain terminal pier lebih efisien dibandingkan desain terminal linear karena terminal pier memiliki moving walkways yang lebih sedikit serta jarak berjalan yang lebih pendek $210 \mathrm{~m}$ dibandingkan dengan desain terminal linear. Selain itu, dari hasil analisis nilai LOS dapat diketahui bahwa hingga tahun 2031 terdapat 4 fasilitas terminal penumpang bandara yang memilliki nilai LOS dibawah C. Sehingga dapat disimpulkan bahwa pada tahun 2031 desain linear sudah tidak sesuai untuk Bandara NYIA sehingga pada tahun tersebut perlu dilakukan pengembangan desain terminal.
\end{abstract}

Kata Kunci-bandara NYIA, terminal bandara, konsep linear, konsep pier, jarak berjalan, level of service.

\section{PENDAHULUAN}

$\mathrm{A}$ KTIVITAS Bandara Adisucipto setiap tahunnya terus mengalami peningkatan, baik dari jumlah penumpang, kargo, maupun pesawat. Berdasarkan data total pergerakan lalu lintas angkatan udara dari PT Angkasa Pura I (Persero), pada tahun 2002 jumlah penumpang di Bandara Adisucipto sebanyak 917.714 penumpang dan meningkat hingga
4.291.646 penumpang pada tahun 2011 [1]. Untuk jumlah kargo di Bandara Adisucipto pada tahun 2002 sebanyak 2.602.279 ton dan meningkat hingga 12.850 .482 ton pada tahun 2011 [1]. Sedangkan untuk jumlah pesawat yang datang dan berangkat di Bandara Adisucipto ada sebanyak 12.010 pesawat dan meningkat hingga 51.216 pesawat pada tahun 2011 [1]. Namun Bandara Adisucipto ini didesain dengan kapasitas penumpang yang hanya 1,2 juta penumpang per tahunnya, maka sejak tahun 2011 Bandara Adisucipto sudah dikatakan over capacity dengan jumlah penumpang mencapai 4 juta lebih per tahun [2].

Salah satu solusi dari over capacity ini adalah dengan menaikkan kapasitas bandara dengan cara memperluas fasilitas landside maupun airside. Keterbatasan lahan, menyebabkan Menteri Perhubungan bersama dengan Gubernur Daerah Istimewa Yogyakarta memutuskan untuk memindahkan Bandara ke Kabupaten Kulonprogo, tepatnya di Kecamatan Temon [3]. Bandara baru ini akan diberi nama New Yogyakarta International Airport (NYIA). Bandara Adisucipto akan digunakan kembali oleh TNI Angkatan Udara untuk kepentingan militer.

Terminal penumpang bandara New Yogyakarta International Airport (NYIA) didesain dengan dua desain yang berbeda, desain pier yang disajikan oleh AGA-Letiste (perusahaan asing yang berasal dari Republik Ceko) melalui website-nya dan desain linear yang direalisasikan oleh PT Angkasa Pura 1 (Persero). Perbedaan desain tersebut menimbulkan pertanyaan mengenai efisiensi konsep desain terminal linear yang digunakan dalam memenuhi pertumbuhan jumlah penumpangnya. Untuk menjawab pertanyaan ini, dibutuhkan suatu evaluasi terhadap konsep desain terminal penumpang bandara NYIA guna mencegah permasalahan ketidaknyamanan. Hasil akhir dari studi ini dapat memberikan gambaran pada jumlah penumpang berapa desain pier lebih sesuai dibandingkan dengan desain linear.

\section{METODE PENELITIAN}

Data jumlah penumpang Bandara Adisucipto Yogyakarta selama 10 tahun terakhir yang akan diolah menggunakan metode peramalan ARIMA dan Triple Exponential Smoothing [4]. Dua metode peramalan tersebut digunakan untuk mengetahui metode mana yang hasilnya paling mendekati kondisi eksisting jumlah penumpang Bandara Adisucipto Yogyakarta pada tahun 2016. Setelah didapatkan metode peramalan yang paling mendekati, kemudian metode 
peramalan tersebut digunakan untuk meramalkan jumlah penumpang pada tahun 2017-2040. Hasil dari peramalan jumlah penumpang tersebut digunakan untuk menghitung kebutuhan luasan terminal penumpang [5][6] di Bandara New Yogyakarta International Airport (NYIA) serta untuk mengetahui pertumbuhan pergerakan penumpangnya. Setelah itu dilakukan evaluasi desain terminal penumpang untuk mengetahui efisiensi dari desain terminal linear yang digunakan di Bandara NYIA. Terakhir dilakukan analisis nilai level of service (LOS) [7] pada terminal penumpang bandara NYIA untuk mengetahui pada tahun berapa desain terminal linear perlu dikembangkan.

Tabel 1.

Diagram Alir Penyelesaian Studi

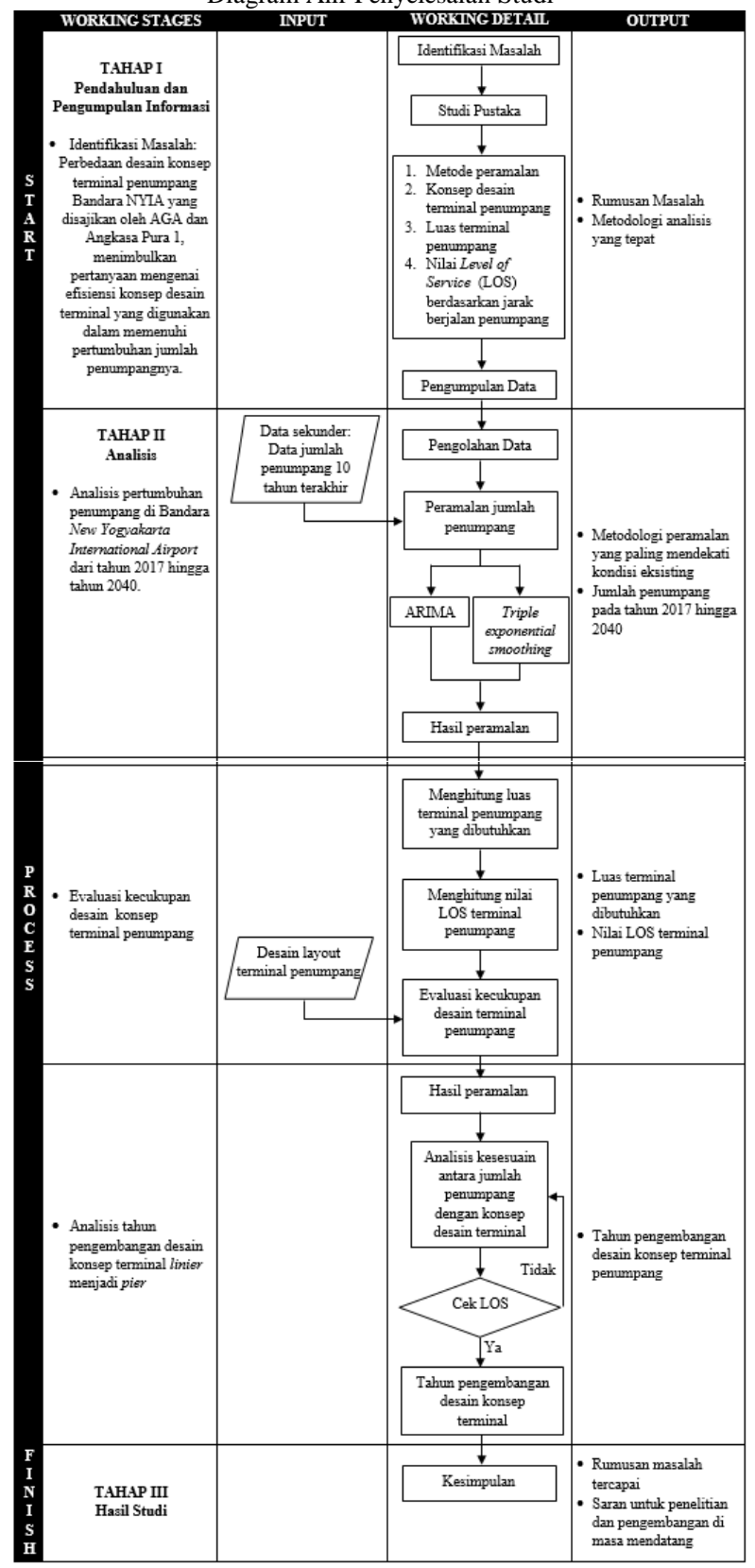

\section{ANALISIS DATA}

\section{A. Pergerakan Penumpang}

Volume pergerakan penumpang digunakan untuk meramalkan pertumbuhan pergerakan penumpang pada tahun rencana, yaitu tahun 2040. Berdasarkan data sekunder yang diperoleh dari PT Angkasa Pura I (Persero), volume pergerakan penumpang di Bandara Adisucipto Yogyakarta pada tahun 2007-2016 mengalami trend yang semakin meningkat.

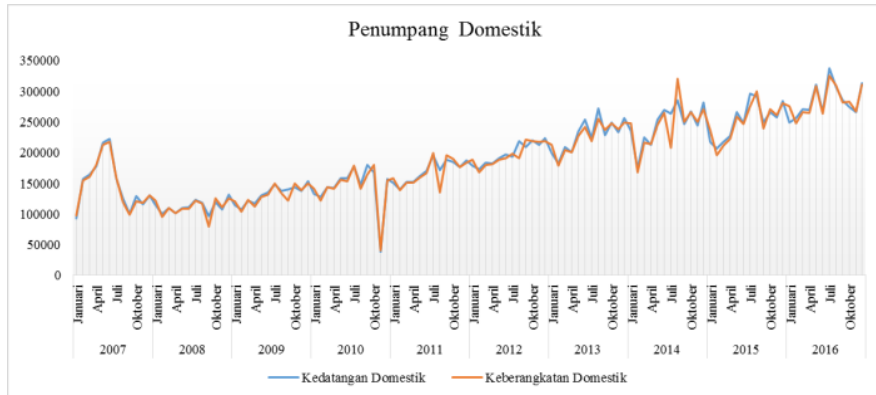

Gambar 1. Grafik Jumlah Penumpang Domestik

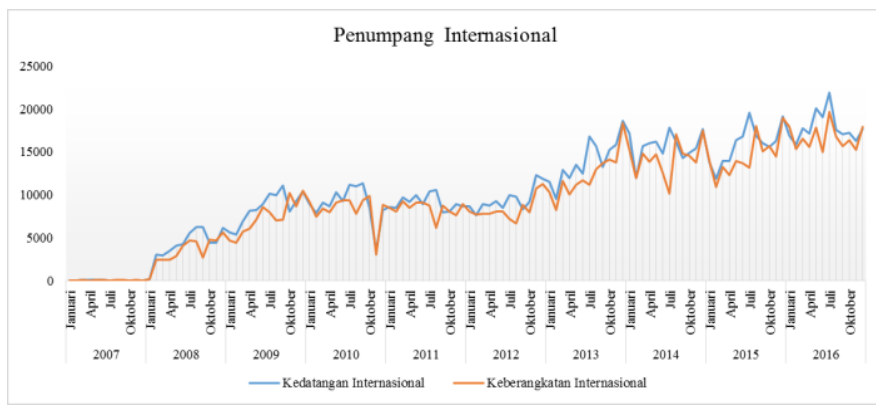

Gambar 2. Grafik Jumlah Penumpang Internasional

Tabel 2.

Pertumbuhan Pergerakan Penumpang Tahun 2007-2016

\begin{tabular}{ccr}
\hline \hline Tahun & Jumlah & Pertumbuhan \\
\hline 2007 & $3,625,652$ & Unknown \\
2008 & $2,792,031$ & $-22.99 \%$ \\
2009 & $3,368,381$ & $20.64 \%$ \\
2010 & $3,694,964$ & $9.70 \%$ \\
2011 & $4,292,016$ & $16.16 \%$ \\
2012 & $4,998,028$ & $16.45 \%$ \\
2013 & $5,776,073$ & $15.57 \%$ \\
2014 & $6,236,578$ & $7.97 \%$ \\
2015 & $6,380,336$ & $2.31 \%$ \\
2016 & $7,214,365$ & $13.07 \%$ \\
& Rata-rata & $7.89 \%$ \\
\hline \hline
\end{tabular}

Berdasarkan perhitungan pertumbuhan pergerakan penumpang, dapat diketahui bahwa pertumbuhan penumpang di Bandara Adisucipto Yogyakarta mengalami peningkatan rata-rata sebesar $7.89 \%$. Sedangkan pada tahun 2008 terjadi penurunan jumlah penumpang sebesar $22.99 \%$.

\section{B. Peramalan Metode ARIMA}

Peramalan ARIMA dapat dilakukan jika parameter model signifikan, residual memenuhi syarat white noise dan asumsi distribusi normal terpenuhi. Dari hasil analisis untuk model peramalan ARIMA, didapat 4 pendugaan model ARIMA sebagai berikut.

1) $\operatorname{ARIMA}(2,1,1)(1,0,0)^{12}$ 
2) ARIMA $(2,1,1)(1,1,0)^{12}$

3) ARIMA $(1,1,1)(1,1,1)^{12}$

4) $\operatorname{ARIMA}(0,1,1)(0,1,1)^{12}$

Dari hasil estimasi parameter untuk masing-masing model ARIMA didapat nilai $p$-value $<0.05$, sehingga dapat dikatakan bahwa semua parameter untuk semua model ARIMA sudah signifikan pada $\alpha=5 \%$. Berdasarkan hasil estimasi Modified Box-Pierce (Ljung-Box), dapat diketahui bahwa semua model sudah memenuhi syarat white noise karena nilai $p$-value > 0.05 . Sedangkan dari hasil uji distribusi normal didapat nilai $p$-value $<0.05$, sehingga dapat disimpulkan bahwa semua model belum memenuhi asumsi distribusi normal.

Walaupun semua parameter untuk semua model ARIMA sudah signifikan, data penumpang keberangkatan domestik di Bandara Adisucipto Yogyakarta tahun 2007-2016 tidak dapat diramalkan dengan model ARIMA karena tidak ada satupun model yang memenuhi asumsi distribusi normal.

\section{Peramalan Metode Triple Exponential Smoothing}

Langkah awal peramalan dengan metode Triple Exponential Smoothing adalah penentuan model dan nilai dugaan parameter smoothing terbaik. Dengan menggunakan bantuan aplikasi Eviews, diperoleh model terbaik untuk peramalan jumlah penumpang di Bandara Adisucipto Yogyakarta pada tahun 2007-2016 sebagai berikut:

1) Model terbaik untuk penumpang keberangkatan domestik adalah model Multiplicative Holt-Winters method with additive errors (A,M,M). Dengan konstanta smoothing terbaik $\alpha=0.246772 ; \beta=0.011150 ;$ dan $\gamma=0.000000$, didapat nilai MSE sebesar 5.69E+08.

2) Model terbaik untuk penumpang keberangkatan internasional adalah model Additive Holt-Winters method with additive errors (A,A,A). Dengan konstanta smoothing terbaik $\alpha=0.381475 ; \beta=0.000000 ;$ dan $\gamma=0.000000$ didapat nilai MSE sebesar 2251667.

3) Model terbaik untuk penumpang kedatangan domestik adalah model Multiplicative Holt-Winters method with additive errors (A,M,M). Dengan konstanta smoothing terbaik $\alpha=0.335237 ; \beta=0.000000$; dan $\gamma=0.000000$, didapatkan nilai MSE sebesar 4.74E+08.

4) Model terbaik untuk penumpang kedatangan internasional adalah model Additive Holt-Winters method with additive errors (A,A,A). Dengan konstanta smoothing terbaik $\alpha=$ $0.542948 ; \beta=0.000000 ;$ dan $\gamma=0.000000$ didapat nilai MSE sebesar 2105743.

Setelah didapatkan model terbaik untuk peramalan jumlah penumpang metode Triple Exponential Smoothing, kemudian didapat hasil peramalan jumlah penumpang keberangkatan dan kedatangan di Bandara Adisucipto Yogyakarta pada tahun 2017-2040.

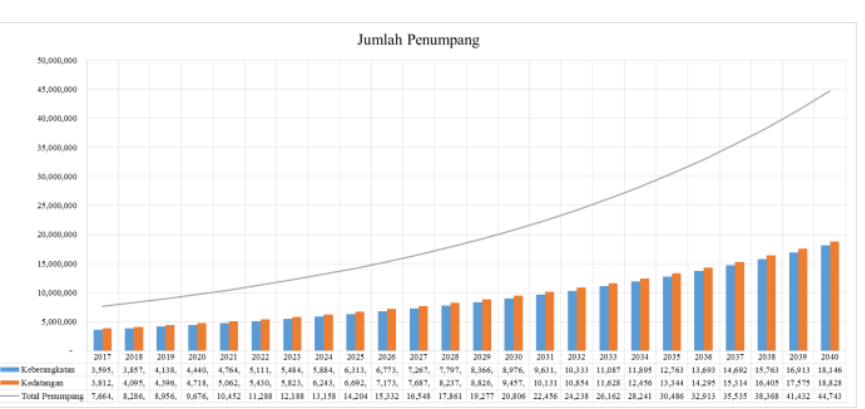

Gambar 3. Hasil Peramalan Jumlah Penumpang

Berdasarkan hasil peramalan, dapat diketahui pertumbuhan pergerakan penumpang di Bandara Adisucipto Yogyakarta pada tahun 2017-2040 mengalami peningkatan rata-rata sebesar $7.90 \%$.

\section{Perhitungan Peak Hour}

Berdasarkan data jumlah penumpang keberangkatan dan kedatangan harian di Bandara Adisucipto Yogyakarta pada tanggal 4-10 Februari 2017, didapat jumlah penumpang saat peak hour pada kondisi actual dan scheduled dengan menggunakan metode IATA.

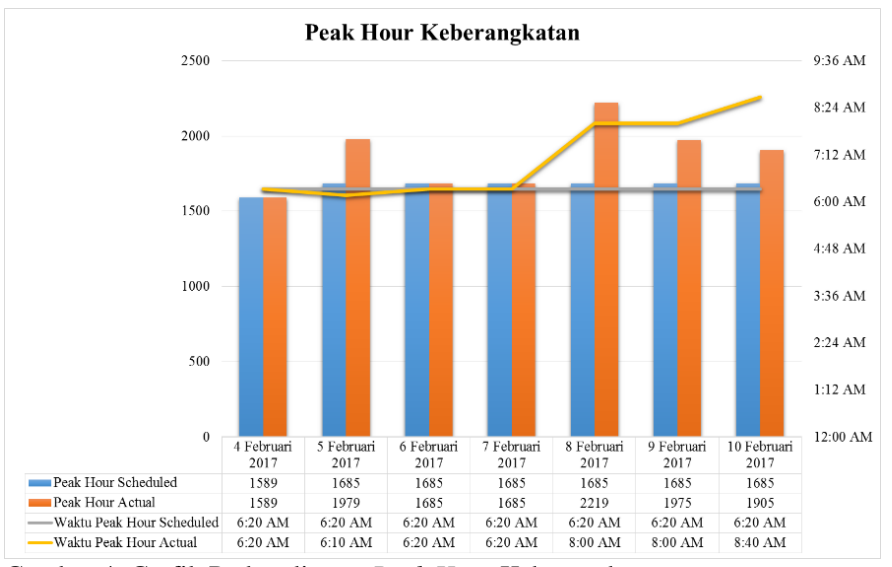

Gambar 4. Grafik Perbandingan Peak Hour Keberangkatan

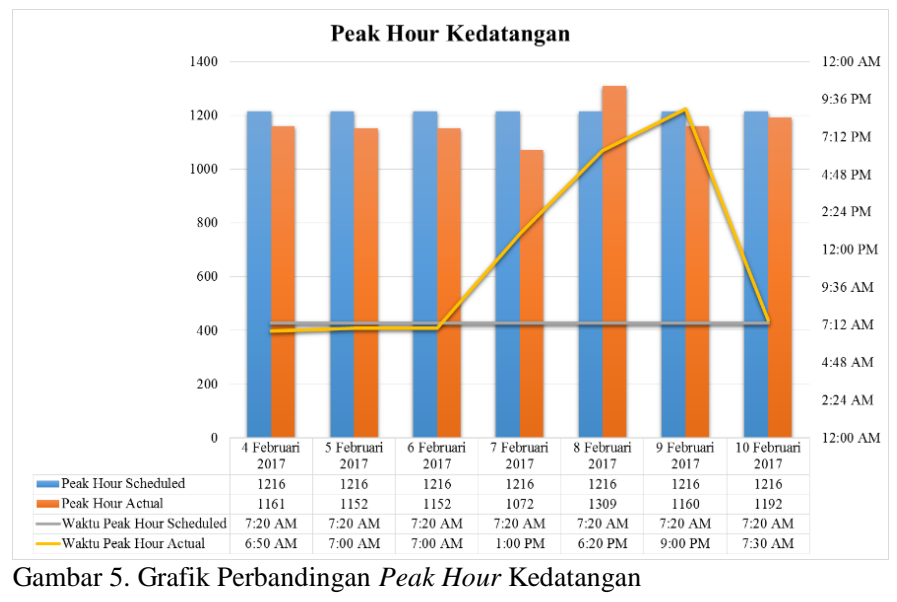


Dengan menggunakan persentase nilai TPHP yang dikeluarkan oleh FAA, dapat dihitung jumlah penumpang peak hour pada tahun 2016.

$$
\begin{array}{ll}
\text { Penumpang tahun } 2016 & =7,214,365 \rightarrow \mathrm{TPHP}=0.05 \% \\
\text { Penumpang keberangkatan } & =3,598,540 \text { penumpang } \\
\text { Penumpang kedatangan } & =3,613,318 \text { penumpang } \\
\text { Peak hour keberangkatan } & =3,598,540 \times 0.05 \%=1800 \\
\text { Peak hour kedatangan } & =3,613,318 \times 0.05 \%=1807
\end{array}
$$

Setelah didapat jumlah penumpang keberangkatan dan kedatangan saat peak hour, kemudian didapat perbandingan antara peak hour hasil perhitungan IATA dengan FAA.

$$
\text { Tabel } 3 .
$$

Hasil Perhitungan Rasio Peak Hour

\begin{tabular}{cccc}
\hline \hline NO & Perbandingan & Keberangkatan & Kedatangan \\
\hline 1 & $\begin{array}{c}\text { IATA Actual / } \\
\text { IATA Scheduled }\end{array}$ & $111.42 \%$ & $96.31 \%$ \\
2 & $\begin{array}{c}\text { IATA Scheduled / } \\
\text { FAA }\end{array}$ & $92.89 \%$ & $67.29 \%$ \\
3 & IATA Actual / & $103.50 \%$ & $64.89 \%$ \\
& FAA & $102.60 \%$ & $76.18 \%$ \\
\hline \hline
\end{tabular}

Dari hasil perhitungan rasio peak hour, dapat diketahui bahwa penumpang keberangkatan saat peak hour pada kenyataannya $2.60 \%$ lebih besar dari perkiraan penumpang peak hour menggunakan persentase dari FAA. Sedangkan untuk jumlah penumpang kedatangan saat peak hour pada kenyataannya $23.82 \%$ lebih kecil dari perkiraan peak hour menggunakan persentase dari FAA.

Perhitungan penumpang peak hour untuk penumpang keberangkatan dan kedatangan, dilakukan dengan mengalikan jumlah penumpang tahunan hasil peramalan dengan persentase TPHP dan rasio peak hour.

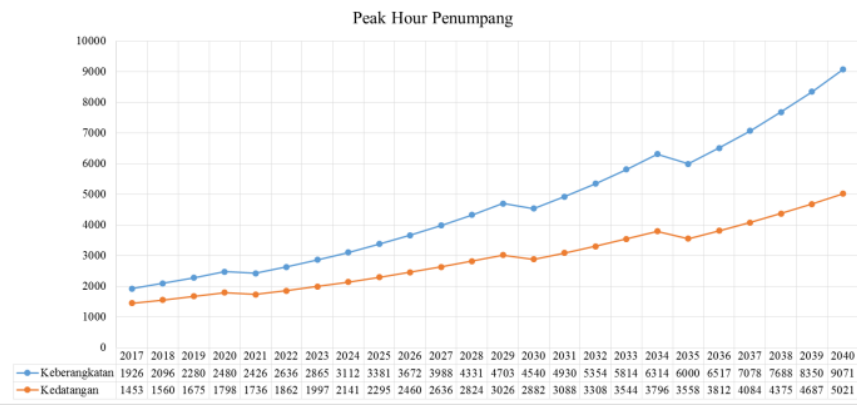

Gambar 6. Hasil Perhitungan Penumpang Saat Peak Hour

\section{E. Perhitungan Luasan Terminal Penumpang}

Luasan kebutuhan terminal penumpang Bandara New Yogykarta International Airport pada tahun 2017-2040 dihitung dengan menggunakan standar SNI 03-7046-2004 dan SKEP/77/VI/2005.

Perhitungan kebutuhan luasan terminal penumpang di Bandara NYIA pada tahun 2040, dilakukan dua kali perhitungan karena terdapat perbedaan antara hasil peramalan yang penulis lakukan dengan yang direalisasikan oleh pihak Angkasa Pura I. Dari hasil perhitungan yang penulis lakukan, jumlah penumpang yang dibutuhkan pada tahun 2040 adalah 45 juta penumpang per tahun. Sedangkan pihak Angkasa Pura I mendesain Bandara NYIA dengan kapasitas 20 juta penumpang per tahun.
Dari hasil perhitungan, didapat kebutuhan luasan terminal penumpang di Bandara NYIA untuk kapasitas 20 juta penumpang per tahun adalah $256,616 \mathrm{~m}^{2}$ atau setara dengan 34 kali lapangan bola. Sedangkan untuk kapasitas 45 juta penumpang per tahun, luasan terminal penumpang yang dibutuhkan adalah 512,990 $\mathrm{m}^{2}$ atau setara dengan $68 \mathrm{kali}$ lapangan bola.

\section{F. Nilai Level of Service Fasilitas Terminal Penumpang}

Analisis nilai level of service dilakukan pada fasilitas checkin area, ruang tunggu keberangkatan, gate hold room area, baggage claim area, dan passport area. Perhitungan dilakukan dengan menggunakan standar level of service dari IATA.

Tabel 4.

Nilai LOS Kapasitas Penumpang 45 Juta Penumpang

\begin{tabular}{|l|c|c|c|c|c|c|}
\hline \multirow{2}{*}{ Fasilitas } & \multicolumn{7}{|c|}{ Nilai Level of Service } \\
\cline { 2 - 8 } & 2017 & 2020 & 2025 & 2030 & 2035 & 2040 \\
\hline Check-in area & $\mathrm{A}$ & $\mathrm{A}$ & $\mathrm{A}$ & $\mathrm{A}$ & $\mathrm{A}$ & $\mathrm{B}$ \\
\hline Ruang tunggu keberangkatan & $\mathrm{A}$ & $\mathrm{A}$ & $\mathrm{A}$ & $\mathrm{A}$ & $\mathrm{A}$ & $\mathrm{C}$ \\
\hline Gate hold room area & $\mathrm{A}$ & $\mathrm{A}$ & $\mathrm{A}$ & $\mathrm{A}$ & $\mathrm{A}$ & $\mathrm{A}$ \\
\hline Baggage claim area & $\mathrm{A}$ & $\mathrm{A}$ & $\mathrm{A}$ & $\mathrm{A}$ & $\mathrm{A}$ & $\mathrm{B}$ \\
\hline Passport area keberangkatan & $\mathrm{A}$ & $\mathrm{A}$ & $\mathrm{A}$ & $\mathrm{A}$ & $\mathrm{A}$ & $\mathrm{C}$ \\
\hline Passport area kedatangan & $\mathrm{A}$ & $\mathrm{A}$ & $\mathrm{A}$ & $\mathrm{A}$ & $\mathrm{A}$ & $\mathrm{C}$ \\
\hline
\end{tabular}

Tabel 5 .

Nilai LOS Kapasitas Penumpang 20 Juta Penumpang

\begin{tabular}{|l|c|c|c|c|c|c|}
\hline \multirow{2}{*}{ Fasilitas } & \multicolumn{7}{|c|}{ Nilai Level of Service } \\
\cline { 2 - 8 } & 2017 & 2020 & 2025 & 2030 & 2035 & 2040 \\
\hline Check-in area & $\mathrm{A}$ & $\mathrm{A}$ & $\mathrm{A}$ & $\mathrm{C}$ & $\mathrm{E}$ & $\mathrm{F}$ \\
\hline Ruang tunggu keberangkatan & $\mathrm{A}$ & $\mathrm{A}$ & $\mathrm{B}$ & $\mathrm{C}$ & $\mathrm{D}$ & $\mathrm{F}$ \\
\hline Gate hold room area & $\mathrm{A}$ & $\mathrm{A}$ & $\mathrm{A}$ & $\mathrm{A}$ & $\mathrm{C}$ & $\mathrm{E}$ \\
\hline Baggage claim area & $\mathrm{A}$ & $\mathrm{A}$ & $\mathrm{A}$ & $\mathrm{C}$ & $\mathrm{D}$ & $\mathrm{F}$ \\
\hline Passport area keberangkatan & $\mathrm{A}$ & $\mathrm{A}$ & $\mathrm{B}$ & $\mathrm{D}$ & $\mathrm{E}$ & $\mathrm{F}$ \\
\hline Passport area kedatangan & $\mathrm{A}$ & $\mathrm{A}$ & $\mathrm{B}$ & $\mathrm{C}$ & $\mathrm{D}$ & $\mathrm{E}$ \\
\hline
\end{tabular}

Dari hasil perhitungan, dapat dilihat bahwa nilai LOS untuk kapasitas penumpang 45 juta penumpang jauh lebih baik dibandingkan dengan nilai LOS pada kapasitas 20 juta penumpang. Hal ini disebabkan karena pada nilai LOS dengan kapasitas 20 juta penumpang, mulai tahun 2030 terdapat nilai LOS yang dibawah C. Sedangkan untuk hasil perhitungan nilai LOS dengan kapasitas 45 juta penumpang, hingga tahun rencana pada tahun 2040 nilai LOS yang dihasilkan semua diatas $\mathrm{C}$.

\section{G. Analisis Tahun Pengembangan Desain Terminal}

Analisis dilakukan dengan melihat nilai LOS pada kapasitas 20 juta penumpang per tahun. Analisis nilai LOS dilakukan pada fasilitas check-in area, ruang tunggu keberangkatan, baggage claim area, gate hold room area, passport area kedatangan, dan passport area keberangkatan.

Penentuan tahun pengembangan untuk masing-masing fasilitas, didapat dari hasil analisis nilai LOS yang dibawah C.

Tabel 6.

Rekapan Tahun Pengembangan Terminal

\begin{tabular}{lc}
\hline \multicolumn{1}{c}{ Fasilitas Terminal } & Tahun Pengembangan \\
\hline Check-in area & 2031 \\
Ruang tunggu keberangkatan & 2031 \\
Baggage claim area & 2036 \\
Gate hold room area & 2032 \\
Passport area keberangkatan & 2028 \\
Passport area kedatangan & 2031 \\
\hline \hline
\end{tabular}


Dari hasil analisis nilai LOS, dapat dilihat bahwa dari 6 fasilitas yang dilakukan analisis, hingga tahun 2031 terdapat 4 fasilitas terminal penumpang bandara yang memiliki nilai LOS dibawah C. Maka dapat disimpulkan bahwa pada tahun 2031 desain linear sudah tidak sesuai untuk Bandara NYIA. Sehingga pada tahun 2031 perlu dilakukan pengembangan desain terminal di Bandara NYIA

\section{H. Evaluasi Desain Terminal Penumpang}

Evaluasi desain dilakukan untuk mengetahui efisiensi terminal linear yang digunakan pada terminal penumpang Bandara NYIA dengan kapasitas 20 juta penumpang per tahun. Evaluasi dilakukan dengan melihat jarak berjalan penumpang untuk terminal keberangkatan dan kedatangan pada desain terminal linear dan pier.

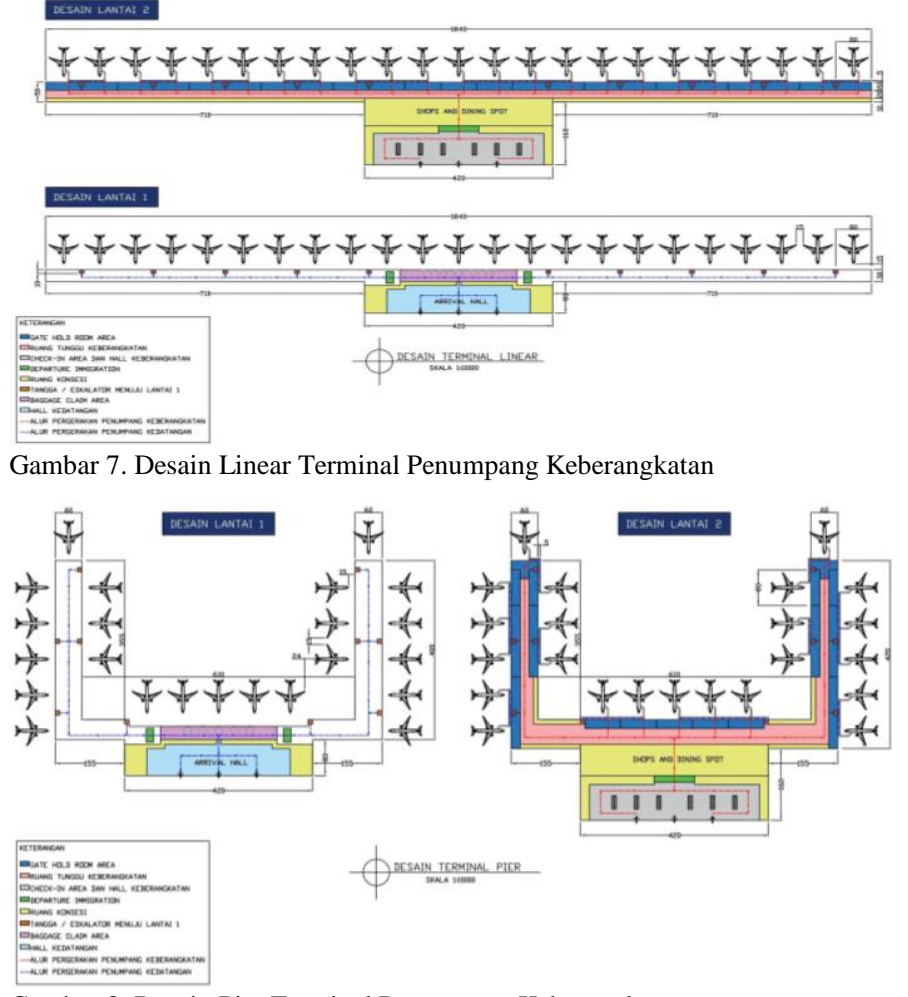

Gambar 8. Desain Pier Terminal Penumpang Keberangkatan

Dari gambar 7 dan 8, dapat diketahui jarak berjalan penumpang antar fasilitas di Bandara NYIA untuk desain terminal linear maupun pier. Dengan asumsi kecepatan pejalan kaki adalah $1,3 \mathrm{~m} / \mathrm{s}$, dapat diketahui waktu tempuh yang dibutuhkan di terminal penumpang Bandara NYIA.

Tabel 7.

Hasil Analisis Jarak Berjalan dan Waktu Tempuh

\begin{tabular}{|c|c|c|c|c|c|c|}
\hline \multirow[t]{2}{*}{ Terminal } & \multicolumn{2}{|c|}{ Fasilitas } & \multicolumn{2}{|c|}{$\begin{array}{c}\begin{array}{c}\text { Jarak Berjalan } \\
\text { (m) }\end{array} \\
\end{array}$} & \multicolumn{2}{|c|}{$\begin{array}{c}\begin{array}{c}\text { Waktu Tempuh } \\
\text { (detik) }\end{array} \\
\end{array}$} \\
\hline & Dari & $\mathbf{K e}$ & Linear & Pier & Linear & Pier \\
\hline \multirow{5}{*}{ Keberangkatan } & Hall & Check-in & 120 & 120 & 93 & 93 \\
\hline & Check-in & Immigration & 210 & 210 & 162 & 162 \\
\hline & Immigration & Ruang Tunggu & 975 & 765 & 750 & 589 \\
\hline & Ruang Tunggu & Gate & 10 & 10 & 8 & 8 \\
\hline & Gate & Pesawat & 40 & 40 & 31 & 31 \\
\hline \multicolumn{3}{|c|}{ TOTAL KEBERANGKATAN } & 1355 & 1145 & 1044 & 883 \\
\hline \multirow{3}{*}{ Kedatangan } & Pesawat & Immigration & 740 & 620 & 570 & 477 \\
\hline & Immigration & Baggage Claim & 160 & 160 & 123 & 123 \\
\hline & $\begin{array}{c}\text { Baggage } \\
\text { Claim }\end{array}$ & Hall & 80 & 80 & 62 & 62 \\
\hline \multicolumn{3}{|c|}{ TOTAL KEDATANGAN } & 980 & 860 & 755 & 662 \\
\hline
\end{tabular}

Dari hasil analisis, dapat diketahui bahwa desain pier memiliki total jarak berjalan serta waktu tempuh yang lebih singkat dibandingkan dengan desain linear. Pada terminal keberangkatan, desain pier memiliki jarak berjalan lebih pendek $210 \mathrm{~m}$ dibandingkan dengan desain linear. Sedangkan untuk terminal kedatangan, desain pier memiliki jarak berjalan yang lebih pendek $120 \mathrm{~m}$ dibandingkan dengan desain linear.

Berdasarkan standar IATA, jarak paling jauh untuk penumpang berjalan kaki agar penumpang tetap merasa nyaman adalah $300 \mathrm{~m}$. Karena jarak berjalan penumpang yang dibutuhkan untuk desain terminal linear maupun pier di Bandara NYIA melebihi $300 \mathrm{~m}$, maka dibutuhkan moving walkways untuk mengurangi jarak berjalan penumpang agar kenyamanan penumpang tetap terjaga.

Pada terminal keberangkatan, moving walkways yang dibutuhkan untuk desain terminal linear adalah 22 unit dan untuk desain terminal pier hanya membutuhkan 16 unit. Sedangkan pada terminal kedatangan, moving walkways yang dibutuhkan untuk desain terminal linear adalah 8 unit dan untuk desain terminal pier hanya membutuhkan 6 unit.

\section{KESIMPULAN DAN SARAN}

\section{A. Kesimpulan}

Berdasarkan hasil analisis yang telah dilakukan, maka diperoleh kesimpulan sebagai berikut:

\section{1) Pertumbuhan Penumpang di Bandara NYIA}

Data jumlah penumpang Bandara Adisucipto Yogyakarta tahun 2007-2016 tidak dapat diramalkan dengan metode ARIMA. Hal ini disebabkan karena tidak ada satupun model ARIMA yang memenuhi asumsi distribusi normal.

Dengan metode Triple Exponential Smoothing, didapat jumlah penumpang di Bandara NYIA pada tahun 2040 yaitu $44,743,611$ penumpang, dengan total penumpang keberangkatan sebesar $25,914,700$ penumpang dan total penumpang kedatangan sebesar 18,828,911 penumpang.

Dari hasil peramalan dengan metode Triple Exponential Smoothing dapat diketahui pertumbuhan pergerakan penumpang di Bandara NYIA pada tahun 2017-2040 mengalami peningkatan rata-rata sebesar $7.90 \%$ setiap tahunnya.

\section{2) Efisiensi Desain Terminal Penumpang Bandara NYIA}

Berdasarkan jarak berjalan penumpang serta jumlah unit moving walkways yang dibutuhkan pada terminal penumpang bandara dengan kapasitas 20 juta penumpang per tahun, dapat disimpulkan bahwa desain terminal pier lebih efisien dibandingkan desain terminal linear. Karena desain terminal pier memiliki jarak berjalan yang lebih pendek $210 \mathrm{~m}$ serta moving walkways yang lebih sedikit dibandingkan dengan desain terminal linear.

\section{3) Tahun Pengembangan Desain Terminal Penumpang}

Dari hasil analisis nilai LOS, dapat dilihat bahwa dari 6 fasilitas yang dilakukan analisis nilai LOS, hingga tahun 2031 terdapat 4 fasilitas terminal penumpang bandara yang memiliki nilai LOS dibawah C. Maka dapat disimpulkan bahwa pada tahun 2031 desain linear sudah tidak sesuai untuk Bandara NYIA. Sehingga pada tahun 2031 perlu dilakukan pengembangan desain terminal di Bandara NYIA. 


\section{B. Saran}

Metode peramalan yang digunakan dalam studi ini hanya 2 metode, yaitu metode ARIMA dan Triple Exponential Smoothing. Maka untuk penelitian selanjutnya diharapkan dapat menggunakan metode peramalan yang lain, sehingga diperoleh model alternatif untuk menghasilkan peramalan yang lebih baik.

Perencanaan desain layout terminal yang dilakukan dalam studi ini, hanya merencanakan desain terminal penumpang keberangkatan dengan menggunakan konsep terminal linear dan pier. Maka untuk penelitian selanjutnya diharapkan dapat menganalisis serta mendesain terminal penumpang dengan konsep terminal satelit, transporter, maupun kombinasi. Sehingga dapat diperoleh desain terminal yang paling efisien dalam memenuhi pertumbuhan jumlah penumpang di Bandara NYIA.

\section{DAFTAR PUSTAKA}

[1]

]

A. P. I, "Total Pergerakan Lalu Lintas Angkutan Udara PT. Persero Angkasa Pura I Bandara: Adisucipto - 2007-2016,” 2016.

M. S. Zuhri, "Analisis Perubahan Grafik Perjalanan Kereta Api Lintas Yogyakarta-Kutoarjo Akibat Rencana Pengoperasian Kereta Api Bandara Pengganti Adisucipto," Universitas Gadjah Mada Yogyakarta, 2015.

[3] P. D. D. I. Yogyakarta, Penetapan Lokasi Pembangunan Untuk Pengembangan Bandara Baru di Daerah Istimewa Yogyakarta. 2015.

D. . Hanke, J.E. dan Wichern, Business Forecasting Eight Edition. New Jersey: Pearson Prentice Hall, 2005.

B. S. Nasional, SNI 03-7046-2004 Terminal Penumpang Bandar Udara. 2004

D. J. P. Udara, Peraturan Direktur Jenderal Perhubungan Udara Nomor: SKEP/77/VI/2005 tentang Persyaratan Teknis Pengoperasian Fasilitas Teknik Bandar Udara. 2005.

I. A. T. Association, Airport Development Reference Manual. Geneva, 2004 